\title{
Provinsi Papua Sebelum Dan Setelah 18 Tahun Pemberian Dana Otonomi Khusus
}

\author{
Rindang Mustikawati ${ }^{1}$, Arief Maulana ${ }^{2}$ \\ ${ }^{I}$ Peneliti di Pusat Kajian Daerah dan Anggaran, Setjen Dewan Perwakilan Daerah RI \\ ${ }^{2}$ Peneliti di Pusat Kajian Daerah dan Anggaran, Setjen Dewan Perwakilan Daerah RI
}

\section{ARTICLE INFORMATION}

Received: July 17, 2020

Revised: November 04, 2020

Accepted: November 12, 2020

Available online: November 13, 2020

\section{KEYWORDS}

Health, Education, Poverty, Papua, Special Autonomy Fund

\section{CORRESPONDENCE}

Phone: +6285399542628

E-mail: maulana_arief@ymail.com

\section{A B S T R A C T}

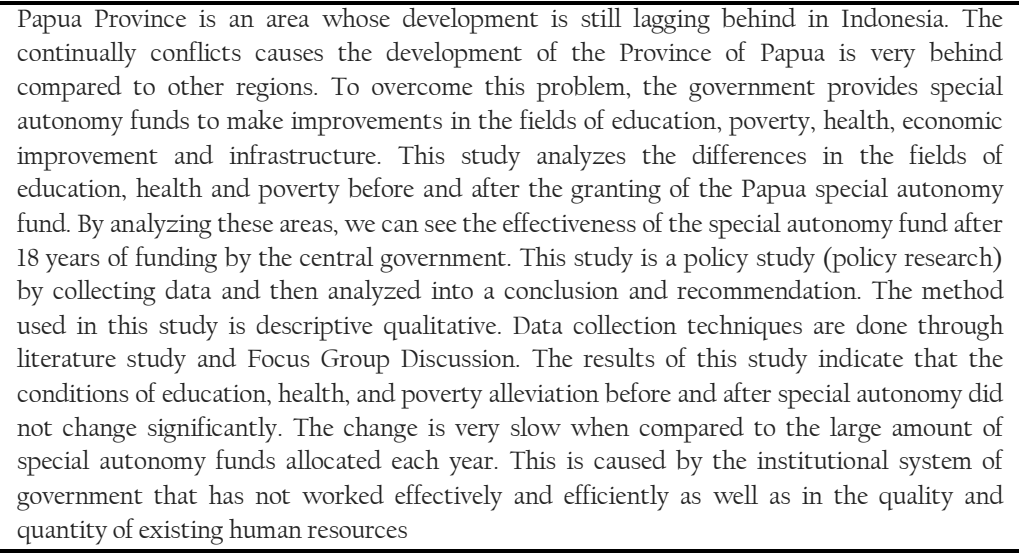
quantity of existing human resources

\section{PENDAHULUAN}

Provinsi Papua merupakan daerah yang pembangunannya masih tertinggal dari provinsi lain di Indonesia. Hal ini dikarenakan Provinsi Papua merupakan daerah konflik yang berkepanjangan. Tim Kajian Papua LIPI yang bekerja sejak 2004 menghasilkan sebuah Road Map Papua pada 2008 yang menunjukkan empat akar masalah Papua. Pertama, proses integrasi wilayah Papua ke dalam Negara Kesatuan Republik Indonesia dipandang oleh pimpinan dan pendukung Papua Merdeka masih bermasalah. Akibatnya, sejak 1964 gerakan untuk menuntut kemerdekaan muncul baik secara politik maupun dengan perlawanan bersenjata bertahan hingga saat ini. Dalam kaitan dengan tuntutan kemerdekaan ini terjadi operasi militer dan kebijakan represif lainnya yang berturut turut dan menimbulkan akar masalah yang kedua, yakni kekerasan negara dan tuduhan pelanggaran hak asasi manusia. Suasana konflik yang berkepanjangan juga menciptakan akar masalah ketiga, yaitu kegagalan pembangunan terutama di bidang pendidikan, kesehatan dan pemberdayaan ekonomi rakyat. Keempat, marginalisasi dan efek diskriminatif terhadap orang asli Papua akibat pembangunan ekonomi konflik politik dan migrasi massal ke Papua yang mulai intensif sejak 1970 (Widjojo \& Budiatri, 2016).

Permasalahan-permasalahan tersebut menyebabkan terjadi kemiskinan, kebodohan dan keterbelakangan di Provinsi Papua. Papua memegang posisi keempat tingkat tertinggi PRDB (pendapatan regional domestik bruto) melalui per kapita di atas 11 juta rupiah yang sebagian besar berasal dari industri yang terkait dengan sumber daya alam. Sayangnya, kondisi ini diikuti dengan sulitnya akses terhadap pelbagai kebutuhan pokok masyarakat (pendidikan, kesehatan dan perekonomian). Misalnya, Survei Kesehatan Penduduk di Papua (1997) memperlihatkan bahwa angka kematian bayi adalah 65 di setiap 1000 kelahiran, dan angka kematian anak adalah 30 per 1000. Rendahnya akses terhadap layanan umum di banyak kasus menyebabkan naiknya urbanisasi. Meskipun demikian, orang asli Papua sebagai mayoritas penduduk yang tinggal di pedesaan atau daerah-daerah terpencil mempunyai akses yang lebih rendah terhadap kebutuhan pokok. Dalam bidang pendidikan $75 \%$ masyarakat Papua tidak memiliki akses terhadap pendidikan yang layak, 50\% tidak pernah mendapatkan pendidikan formal atau tidak lulus dari sekolah dasar, $22 \%$ hanya lulus dari sekolah dasar, $10 \%$ lulus dari sekolah menengah umum, dan $2 \%$ lulus dari universitas (Sugandi, 2008).

Setelah Otonomi khusus berlangsung selama 18 tahun di Provinsi Papua, lndeks Pembangunan Manusia (lPM) tahun 2019 adalah 60,84. Capaian IPM ini bahkan lebih kecil dari beberapa provinsi hasil pemekaran, dan masih berada jauh dibawah IPM Nasional yang mencapai 71,92. Data BPS per Maret 2019 menunjukkan bahwa jumlah penduduk miskin di Provinsi Papua adalah 926.360 jiwa. Itu artinya masih terdapat 27,43\% penduduk Papua yang tergolong miskin, masih sangat tinggi dibandingkan rata-rata nasional di kisaran angka 9,41\%. Jumlah ini telah menempatkan Papua pada ranking pertama sebagai provinsi yang memiliki jumlah penduduk miskin terbanyak di seluruh lndonesia (Badan Pusat Statistik, 2019).

Untuk menyelesaikan permasalahan kemiskinan, kebodohan dan keterbelakangan di Provinsi Papua pemerintah memberikan dana otonomi khusus yang diatur dalam UU Nomor 21 Tahun 2001 tentang Otonomi Khusus bagi Provinsi 
Papua. Disebutkan bahwa, dana otonomi khusus Papua dihitung sebesar 2 persen dari plafon Dana Alokasi Umum (DAU) Nasional yang berlaku selama 20 tahun sejak peraturan tersebut diterbitkan. Dalam pengelolaanya ada kewajiban untuk melakukan alokasi pembiayaan dibidang pendidikan sebesar 30\%, bidang kesehatan sebesar 15\%, bidang ekonomi kerakyatan sebesar 20\%, bidang infrastruktur dasar 20\%. Pemberlakuan kebijakan otonomi khusus bagi Papua diharapkan mampu menjadi sarana percepatan pembangunan di bidang pendidikan tanah Papua sehingga dapat sejajar dengan daerah lain di Indonesia mengingat secara geografis dan politis wilayah ini masih tertinggal (Tabuni et al., 2016).

Dana otonomi khusus yang dikucurkan dari tahun 2002 tersebut tidaklah kecil. Selama tahun 2002-2019 tercatat bahwa dana otonomi khusus yang telah disalurkan pemerintah menembus angka Rp. 84 triliun. Dalam Peraturan Daerah Khusus (Perdasus) Papua Nomor 2 Tahun 2004, pembagian penerimaan keuangan Provinsi Papua ditetapkan sebesar 60\% untuk Kabupaten/Kota dan 40\% untuk Provinsi. Namun setelah 2014 pengalokasiannya diubah oleh Perdasus Nomor 25 Tahun 2013 tentang Pembagian Penerimaan dan Pengelolaan Keuangan Dana Otonomi Khusus yang diubah dengan Perdasus Nomor 13 Tahun 2016, menyatakan bahwa pembagian, pengalokasian dan penyaluran dana otonomi khusus serta pembiayaan untuk program strategis lintas kabupaten/kota adalah $20 \%$ untuk provinsi dan $80 \%$ untuk kabupaten/kota.

Hanya saja, membedah alokasi dana otonomi khusus Papua tak semudah yang dibayangkan, jika sekali saja dana otonomi khusus ini diperkarakan, maka sentimen mengenai ketidakpercayaan masyarakat terhadap pemerintah pusat akan timbul. Ujung-ujungnya, hal tersebut bisa memicu gerakan separatis yang semakin menjadi-jadi. Tapi di sisi lain masih banyak alpa pada pemanfaatan dana otonomi khusus untuk peningkatan kesejahteraan masyarakat. Kapasitas pemerintah daerah dalam mengelola dana ini dirasa masih kurang. Selain itu, dana otonomi khusus ini berkaitan erat dengan politik anggaran. Dengan kata lain, elit Papua kadang menjadi pihak yang diutamakan dalam mendapatkan dana tersebut dengan dalih untuk menjamin bahwa tidak ada keriuhan separatisme di provinsi paling timur Indonesia tersebut.

Dalam tulisan Suharyo, disebutkan bahwa pelaksanaan otonomi khusus di Provinsi Papua dan Aceh yang bertujuan memperbaiki aspek kesejahteraan masyarakat belum sesuai dengan harapan Undang-Undang Otonomi Khusus. Khususnya Provinsi Papua, masalah kemiskinan, terbatasnya infrastruktur, ketertinggalan di bidang pendidikan, pelayanan kesehatan, profesionalisme jajaran di daerah, dan korupsi dikhawatirkan tidak dapat diselesaikan dalam sisa waktu pelaksanaan otonomi khusus yang berakhir tahun 2021 (Suharyo, 2016).

Dalam kajian berjudul hubungan pemerintah pusat dan daerah dalam otonomi khusus Papua Barat menyebutkan bahwa dalam implementasi Otonomi Khusus, pemerintah pusat telah memiliki sistem manajemen pemerintahan berupa pendampingan, pembinaan dan pengawasan. Sistem manajemen mengelola otonomi khusus itu terkait dengan urusan pusat dan daerah menyangkut percepatan kesejahteran, kecerdasan dan kesehatan masyarakat. Namun, fakta di lapangan berbeda, selama ini pendampingan, pembinaan dan pengawasan pemerintah pusat belum terlihat. implementasi otonomi khusus belum sepenuhnya menjawab tuntutan masyarakat dan belum sepenuhnya memberikan kesejahteraan bagi kehidupan masyarakat (Rochendi S \& Saleh, 2017).

Berbeda dengan kajian sebelumnya, kajian ini menganalisis perbedaan dalam bidang pendidikan, kesehatan dan kemiskinan sebelum dan setelah diberikannya dana otonomi khusus Papua. Dengan menganalisis bidang-bidang tersebut kita dapat melihat keefektifan dana otonomi khusus tersebut setelah 18 tahun pemberian dana oleh pemerintah pusat. Kajian ini diharapkan dapat memberi pandangan kepada pemerintah akan efektifitas dana otonomi khusus dan menjadi salah satu referensi dalam menetapkan kebijakan yang akan datang untuk Papua yang lebih baik.

\section{Konsep Desentralisasi Asimetris dan Otonomi Khusus}

Asas desentralisasi dikenal terbagi dalam 2 (dua) kategori, yaitu desentralisasi simetris (symmetric decentralization) dan desentralisasi asimetris (asymmetric decentralization). Sebagaimana dikemukakan oleh Joachim Wehner, bahwa pemberian otonomi yang berbeda atas satu daerah atau wilayah dari beberapa daerah merupakan praktek penyelenggaraan pemerintahan yang cukup umum ditemui dalam pengalaman pengaturan politik di banyak negara. Pengalaman ini berlangsung baik di dalam bentuk negara kesatuan yang didesentralisasikan, maupun dalam format pengaturan federatif. Dalam khasanah ilmu politik dan pemerintahan, pola pengaturan yang tidak sebanding ini disebut sebagai asymmetrical decentralization, asymmetrical devolution, asymmetrical federalism, atau secara umum asymmetrical intergovernmental arrangements (Djojosoekarto, 2008).

Konsep desentralisasi asimetris berkembang dari konsep tentang asymmetric federalism yang diperkenalkan oleh Charles Tarlton pada tahun 1965, dimana terdapat dua jenis asymmetric federation, yakni de facto dan de jure asymmetry. Jenis pertama merujuk pada adanya perbedaan antardaerah dalam hal luas wilayah, potensi ekonomi, budaya dan bahasa, atau perbedaan dalam otonomi, sistem perwakilan atau kewenangan yang timbul karena adanya perbedaan karakteristik tadi. Sedangkan asimetris kedua merupakan produk konstitusi yang didesain secara sadar untuk mencapai tujuan tertentu. Hal ini berhubungan dengan alokasi kewenangan dalam besaran yang berbeda, atau pemberian otonomi dalam wilayah kebijakan tertentu, kepada daerah tertentu saja (Tillin, 2006). Sementara menurut Peter Harris dan Ben Reilly, melalui desentralisasi asimetris ini, wilayah-wilayah tertentu di dalam suatu negara diberikan kewenangan khusus yang tidak diberikan kepada wilayah-wilayah lain (Solossa, 2006).

Desentralisasi asimetris dalam bentuk otonomi khusus merupakan manifestasi desentralisasi yang disesuaikan dengan karakteristik daerah sehingga tidak disamaratakan secara general penerapannya pada seluruh daerah di dalam suatu negara. Ada beberapa negara di dunia yang menerapkan status otonomi khusus terhadap wilayah di negaranya. Sebagai contoh dapat diambil dari pengalaman Kanada dalam mengatur keistimewaan Quebec dalam kesatuannya dengan Federasi Kanada, Mindanao dalam kesatuan politiknya dengan Filipina, Sami Land dalam kesatuannya dengan Norwegia, dan Cina yang membuat kesepakatan dengan Inggris dan Portugal untuk menetapkan status Hong Kong dan Macau sebagai special administrative region.

Dalam konteks Papua dan Indonesia, otonomi khusus ditawarkan melebihi otonomi daerah biasa, karena otonomi ini 
diberikan kepada daerah tertentu yang berarti daerah tersebut mempunyai kelompok gerakan kemerdekaan yang ingin memisahkan dirinya (daerahnya) dari wilayah NKRI. Jadi, secara tidak langsung pemerintah memberikan otonomi khusus ini sebagai bentuk pendekatan damai agar kelompok gerakan tersebut tidak terus bergejolak. Pendekatan dan pemberlakuan desentralisasi asimentris atau otonomi khusus, menurut Hurst Hannum, yang mengistilahkan dengan territorial autonomy, paling tidak terdapat dua manfaat, yaitu (i) sebagai solusi terhadap kemungkinan terjadinya konflik etnis, atau konflikkonflik fisik lainnya, (ii) Sebagai respon demokratis dan damai terhadap keluhan/masalah-masalah kaum minoritas yang hakhaknya selama ini dilanggar/kurang diperhatikan (Solossa, 2006).

Otonomi khusus secara resmi menjadi bagian dari system penyelenggaraan negara melalui Perubahan Kedua UUD 1945. Keberadaan otonomi khusus merupakan salah satu bagian dari pembalikan politik penyelenggaraan negara yang semula bersifat sentralistis dan seragam menuju kepada desentralisasi dan penghargaan kepada keberagaman. Hal ini selaras dengan demokratisasi yang menjadi arus utama reformasi. Demokratisasi penyelenggaraan pemerintahan menghendaki adanya desentralisasi dan penghormatan terhadap keberagaman daerah, sebagaimana Pasal 18B ayat (1) UUD NRI 1945 menyatakan bahwa "Negara menagkui dan menghormati satuansatuan pemerintahan daerah yang bersifat khusus atau bersifat istimewa yang diatur dengan undang-undang".

\section{Desentralisasi Fiskal}

Sebagaimana telah dijelaskan di atas, bahwa desentralisasi merupakan penyerahan wewenang pemerintahan oleh pemerintah pusat kepada daerah otonom (untuk mengatur dan mengurus urusan pemerintahan) dalam sistem Negara Kesatuan Republik Indonesia. Salah satu dampak dari desentralisasi adalah penerapan desentralisasi fiskal dalam sistem pengelolaan keuangan negara.

Dalam pelaksanaannya, konsep desentralisasi fiskal yang dikenal selama ini sebagai money follow function mensyaratkan bahwa pemberian tugas dan kewenangan kepada pemerintah daerah akan diiringi oleh pembagian kewenangan kepada daerah dalam hal penerimaan. Dengan kata lain, penyerahan atau pelimpahan wewenang pemerintah akan membawa konsekuensi anggaran yang diperlukan untuk melaksanakan kewenangan tersebut. Hal ini berarti bahwa hubungan keuangan pusat dan daerah perlu diberikan pengaturan sedemikian rupa. Prosesnya dapat dilakukan melalui mekanisme dana perimbangan, yaitu pembagian penerimaan antartingkatan pemerintahan guna menjalankan fungsi-fungsi pemerintahan dalam kerangka desentralisasi (Haryanto, 2017).

Di Indonesia, pelaksanaan desentralisasi fiskal sebagai salah satu instrumen kebijakan pemerintah mempunyai manfaat antara lain:

a. Secara teoritis, desentralisasi fiskal diharapkan dapat memberi manfaat dalam hal: (i) mengurangi kesenjangan fiskal baik antara pemerintah pusat dan pemerintah daerah (vertical fiscal imbalance) maupun antar daerah yang satu dengan daerah yang lain (horizontal fiscal imbalance); (ii) meningkatkan kualitas pelayanan publik di daerah dan mengurangi kesenjangan pelayanan publik antar daerah; (iii) meningkatkan efisiensi pemanfaatan sumber daya; (iv) peningkatan tata kelola yang transparan dan akuntabel dalam pelaksanaan kegiatan pengalokasian transfer ke daerah sehingga tepat sasaran, tepat waktu, efisien, dan adil; serta (v) mendukung kesinambungan fiskal dalam kebijakan ekonomi makro (Mardiasmo, 2009).

b. Adapun secara praktis, desentralisasi fiskal akan mampu meningkatkan pertumbuhan ekonomi dan kesejahteraan masyarakat (Sasana, 2015).

\section{METODE}

Kajian ini bersifat kajian kebijakan (policy research) yang dirancang untuk memahami satu atau lebih aspek yang berhubungan dengan proses kebijakan, termasuk pembuatan keputusan (decision making), formulasi kebijakan, implementasi kebijakan, yang dilakukan dengan metode studi kualitatif deskriptif. Kajian ini dilakukan dengan menghimpun data hasil publikasi instansi/lembaga yang disandingkan dengan berbagai sumber literatur para ahli dan dokumen perundang-undangan untuk kemudian dianalisa menjadi sebuah kesimpulan dan rekomendasi. Literatur dan dokumen yang dimaksud dapat berupa buku, jurnal, laporan kelembagaan, peraturan perundang-undangan, artikel, berita media, naskah akademik, kertas kebijakan dan literatur lainnya yang berhubungan dengan fokus kajian. Adapun teknik untuk mendapatkan data dalam kajian ini perpaduan antara studi kepustakaan (library research) dan Focus Group Discussion dengan pejabat terkait (Pemprov Papua, DPRD Papua, Kementerian Dalam Negeri, Kementerian Keuangan, Kementerian Kesehatan, DPD RI) serta pakar/ahli yang berkompeten di bidangnya.

Kajian ini menggunakan teknik validasi data untuk menjamin objektifitas dan akurasi penafsiran data. Validitas data diperlukan untuk mengukur sejauh mana interpretasi yang dilakukan oleh peneliti dapat dipercaya. Kajian ini menggunakan teknik validitas data yang dirumuskan oleh John W. Cresswell (2009)

\section{HASIL DAN PEMBAHASAN}

\section{Gambaran Umum Dana Otonomi Khusus Papua}

Menurut UU Nomor 21 Tahun 2001 tentang Otonomi Khusus Bagi Provinsi Papua, dana otonomi khusus Papua adalah anggaran dari pemerintah pusat yang mengalir ke Papua sebagai bentuk kekhususan dan otonomi pemerintah Papua dan Papua Barat untuk mengelola daerahnya sendiri dan sebagai upaya percepatan pembangunan. Proses pengalokasian dana otonomi khusus bagi Papua sudah berjalan 18 tahun sejak tahun 2002. Dana otonomi khusus bagi Papua tercantum di dalam pasal 34 ayat 3 huruf c poin 1 UU tersebut.

Pemberian dana otonomi khusus bagi provinsi papua, pada dasarnya ditujukan untuk menunjang percepatan pelaksanaan otonomi khusus Provinsi Papua, dalam rangka mewujudkan keadilan, penegakan supremasi hukum, penghormatan terhadap HAM, percepatan pembangunan ekonomi, peningkatan kesejahteraan dan kemajuan masyarakat Papua dalam rangka kesetaraan dan keseimbangan dengan kemajuan provinsi lain di Indonesia

Dalam bidang keuangan, kekhususan yang diberikan kepada Provinsi Papua terkait dengan pelaksanaan otonomi khusus adalah berupa adanya pos penerimaan khusus dalam rangka pelaksanaan otonomi khusus. Berdasarkan UU Nomor 21 Tahun 2001 sebagaimana diubah dengan UU Nomor 35 Tahun 2008, diamanatkan bahwa kebijakan pembagian dana dalam rangka otonomi khusus adalah sebagai berikut: 
1. Dana otonomi khusus yang besarnya setara dengan $2 \%$ dari plafon Dana Alokasi Umum (DAU) Nasional, yang terutama ditujukan untuk pembiayaan pendidikan dan kesehatan. Dalam pengelolaanya ada kewajiban untuk melakukan alokasi pembiayaan di bidang pendidikan sebesar 30\%, bidang kesehatan sebesar 15\%, bidang ekonomi kerakyatan sebesar $20 \%$, bidang infrastruktur dasar 20\%.

2. Dana tambahan infrastruktur dalam rangka pelaksanaan otonomi khusus yang besarnya ditetapkan berdasarkan usulan Provinsi. Dana ini bertujuan untuk mempercepat penyediaan infrastruktur di Provinsi Papua dan Papua Barat. Harapannya, dengan adanya dana tambahan infrastruktur dalam waktu 25 tahun sejak 2008, seluruh kabupaten/kota dapat terhubung dengan transportasi darat, laut, dan/atau udara yang berkualitas, sehingga Provinsi Papua/Papua Barat dapat melakukan aktivitas ekonominya secara baik dan menguntungkan sebagai bagian dari sistem perekonomian nasional dan global.

Pada tataran ideal, adanya kewenangan yang besar dengan berlakunya UU Otonomi Khusus Papua, diharapkan mampu menjadi solusi bagi masyarakat yang selama ini termarginalkan oleh pembangunan. Namun pada tataran kenyataannya berbagai persoalan pembangunan mengemuka seakan menjadi problem yang tak terselesaikan melalui pelaksanaan UU Otonomi khusus. Pemberlakuan kebijakan ini oleh sebagian kalangan dianggap belum memberikan perubahan yang signifikan terhadap pelaksanaan fungsi pemerintahan dalam hal melayani (service), membangun (development), dan memberdayakan (empowerment) masyarakat.

Peraturan turunan UU Nomor 35 Tahun 2008 yang harusnya dibuat ternyata tidak direalisasikan. Sehingga implikasinya menyebabkan ada ketidakjelasan urusan pengelolaan dan tumpang tindih pengelolaan kewenangan. Di tingkat daerah ternyata Pemprov Papua, DPRP dan MRP, belum menyelesaikan beberapa Perdasus sebagai implementasi UU Otonomi khusus. Akibatnya, pelaksanaan wewenang, tugas, dan tanggung jawab serta pola dan mekanisme kerja sama belum dibangun, sehingga kinerja yang dihasilkan belum optimal. Selama dana otonomi khusus diturunkan, landasan hukum pengelolaannya hanya melalui peraturan gubernur saja, meskipun pada tahun 2013 peraturan daerah khusus tentang otonomi khusus telah dikeluarkan namun perdasus ini dirasa terlambat pembuatannya.

Dalam Peraturan Daerah Khusus (Perdasus) Nomor 13 Tahun 2016 tentang Perubahan atas Perdasus Provinsi Papua Nomor 25 Tahun 2013 tentang Pembagian Penerimaan dan Pengelolaan Keuangan Dana Otonomi Khusus, Pasal 11 menyebutkan Penerimaan Dana Otonomi Khusus sebagaimana dimaksud dalam Pasal 5 huruf a, setelah dikurangi dengan pembiayaan Program Strategis Lintas Kabupaten/Kota sebagaimana dimaksud dalam Pasal 7 ayat (2), dibagi dengan proporsi 20\% untuk Provinsi Papua dan 80\% untuk Kabupaten/Kota se-Provinsi Papua.

Dana Otonomi Khusus bagian Provinsi Papua sebagaimana dimaksud dalam Pasal 8 ayat (1) Perdasus tersebut digunakan untuk membiayai:

1. Program bidang pendidikan, kesehatan, ekonomi kerakyatan, dan infrastruktur yang merupakan kewenangan provinsi;
2. Bantuan untuk institusi keagamaan, lembaga masyarakat adat Papua, dan yayasan yang bergerak dalam bidang pendidikan, kesehatan, dan ekonomi kerakyatan;

3. Penataan data untuk kebutuhan perencanaan pembangunan otonomi khusus;

4. Monitoring dan evaluasi program dan kegiatan yang dibiayai dari dana otonomi khusus;

5. Peningkatan kinerja keuangan otonomi khusus; dan

6. Belanja operasional pelaksanaan tugas dan fungsi Majelis Rakyat Papua (MRP).

Dana otonomi khusus bagian kabupaten/kota sebagaimana dimaksud dalam Pasal 8 ayat (1) Perdasus tersebut dialokasikan untuk:

1. pembiayaan pelayanan bidang pendidikan minimal 30\% yang penganggarannya untuk membiayai penuntasan buta aksara, pendidikan anak usia dini, pendidikan dasar sembilan tahun, pendidikan menengah, pendidikan nonformal, dan pendidikan tinggi;

2. pembiayaan pelayanan bidang kesehatan minimal $15 \%$ yang penganggarannya dialokasikan untuk pelayanan kesehatan dasar, pelayanan kesehatan rujukan, pencegahan dan pemberantasan penyakit, perbaikan gizi masyarakat, pembinaan kesehatan lingkungan dan sanitasi dasar, dan pelayanan kesehatan dalam situasi bencana;

3. pembiayaan pengembangan ekonomi kerakyatan minimal $25 \%$ yang penganggarannya dialokasikan untuk pembentukan dan pembinaan peran dan fungsi lembaga profesi untuk pengembangan usaha kecil/mikro, perkreditan usaha ekonomi rakyat, subsidi harga kebutuhan bahan pokok, dan pengembangan komoditas unggulan;

4. pembiayaan pembangunan infrastruktur minimal $20 \%$ yang dialokasikan untuk pembangunan prasarana perumahan rakyat, penerangan, air bersih dan telekomunikasi;

5. pembiayaan bantuan afirmasi kepada lembaga keagamaan, lembaga masyarakat adat asli, dan kelompok perempuan yang penganggarannya dialokasikan maksimal 6\%;

6. pembiayaan perencanaan, monitoring dan evaluasi, pelaporan dan pertanggungjawaban keuangan, dan pelaporan program dan kegiatan yang penganggarannya dialokasikan maksimal 2\%; dan

7. pembiayaan program prioritas selain yang disebutkan dalam huruf a, huruf b, huruf c, huruf d, huruf e dan huruf $\mathrm{f}$, dialokasikan maksimal 2\%.

Tabel 1. Dana Otonomi Khusus Papua Selama 18 Tahun (dalam Ribuan Rupiah)

\begin{tabular}{|c|c|c|c|}
\hline Tahun & $\begin{array}{c}\text { Dana Otonomi } \\
\text { Khusus (Rp) }\end{array}$ & $\begin{array}{c}\text { Dana } \\
\text { Tambahan } \\
\text { Infrastruktur } \\
\text { (Rp) }\end{array}$ & Jumlah \\
\hline 2002 & 1.382 .300 .000 & - & 1.382 .300 .000 \\
\hline 2003 & 1.539 .560 .000 & - & 1.539 .560 .000 \\
\hline 2004 & 1.642 .617 .943 & - & 1.642 .617 .943 \\
\hline 2005 & 1.775 .312 .000 & - & 1.775 .312 .000 \\
\hline 2006 & 2.913.284.000 & 536.374 .689 & 3.449 .658 .689 \\
\hline 2007 & 3.295 .748 .000 & 750.000 .000 & 4.045 .748 .000 \\
\hline 2008 & 3.590 .142 .897 & 330.000 .000 & 3.920 .142 .897 \\
\hline 2009 & 2.609.796.098 & 1.470 .000 .000 & 4.079.796.098 \\
\hline 2010 & 2.694 .864 .788 & 800.000 .000 & 3.494 .864 .788 \\
\hline 2011 & 3.157 .459 .547 & 800.000 .000 & 3.957 .459 .547 \\
\hline 2012 & 3.833 .402 .135 & 571.428 .571 & 4.404 .830 .706 \\
\hline 2013 & 4.355 .950 .048 & 571.428 .572 & 4.927 .378 .620 \\
\hline 2014 & 4.777 .070 .975 & 2.000 .000 .000 & 6.777 .070 .975 \\
\hline 2015 & 4.940 .429 .880 & 2.250 .000 .000 & 7.190 .429 .880 \\
\hline
\end{tabular}




\begin{tabular}{crrr}
2016 & 5.395 .051 .859 & 1.200 .000 .000 & 6.595 .051 .859 \\
2017 & 5.616 .816 .931 & 2.625 .000 .000 & 8.241 .816 .931 \\
2018 & 5.580 .152 .407 & 2.400 .000 .000 & 7.980 .152 .407 \\
2019 & 5.808 .230 .158 & 2.824 .446 .537 & 8.632 .676 .695 \\
\hline $\begin{array}{c}\text { Total } \\
\text { Otonomi } \\
\text { khusus }\end{array}$ & 64.908 .189 .666 & 19.128 .678 .369 & 84.036 .868 .035 \\
\multicolumn{4}{l}{ Sumber: BPKAD Papua dan Kementerian Keuangan (2019) }
\end{tabular}

Dari tabel di atas, dapat dilihat bahwa secara umum Dana Otonomi Khusus Papua semakin meningkat dari tahun ke tahun. Akumulasi dana otonomi khusus sampai tahun 2019 sebesar Rp. 84 Triliun. Dana tersebut termasuk dana tambahan infrastruktur sebesar Rp. 19 Triliun.

\section{Implementasi Dana Otonomi Khusus (Kondisi Sebelum dan Sesudah Otonomi Khusus). \\ Bidang Pendidikan}

Bidang Pendidikan merupakan salah satu prioritas dalam program otonomi khusus Papua. Dana otonomi khusus untuk bidang pendidikan diwajibkan untuk dialokasikan sebesar $30 \%$. Dengan alokasi dana yang tidak sedikit tersebut, harusnya tingkat IPM Provinsi Papua juga ikut naik. Namun realitasnya tingkat IPM Provinsi Papua masih menempati peringkat pertama terendah dari provinsi seluruh di Indonesia.

Tabel 2. Indeks Pembangunan Manusia Menurut Provinsi (2019)

\begin{tabular}{|c|c|c|c|}
\hline \multirow{2}{*}{ No. } & \multirow{2}{*}{ Provinsi } & \multicolumn{2}{|c|}{ IPM Menurut Provinsi } \\
\hline & & Nilai IPM & Peringkat \\
\hline 1. & DKI Jakarta & 80.76 & 1 \\
\hline 2. & DI Yogyakarta & 79.99 & 2 \\
\hline 3. & Kalimantan Timur & 76.61 & 3 \\
\hline 4. & Kepulauan Riau & 75.48 & 4 \\
\hline 5. & Bali & 75.38 & 5 \\
\hline 6. & Riau & 73.00 & 6 \\
\hline 7. & Sulawesi Utara & 72.99 & 7 \\
\hline 8. & Banten & 72.44 & 8 \\
\hline 9. & Sumatera Barat & 72.39 & 9 \\
\hline 10. & Jawa Barat & 72.03 & 10 \\
\hline 11. & Aceh & 71.90 & 11 \\
\hline 12. & Sumatera Utara & 71.74 & 12 \\
\hline 13. & Jawa Tengah & 71.73 & 13 \\
\hline 14. & Sulawesi Selatan & 71.66 & 14 \\
\hline 15. & Jawa Timur & 71.50 & 15 \\
\hline 16. & $\begin{array}{l}\text { Kepulauan Bangka } \\
\text { Belitung }\end{array}$ & 71.30 & 16 \\
\hline 17. & Jambi & 71.26 & 17 \\
\hline 18. & Bengkulu & 71.21 & 18 \\
\hline 19. & Sulawesi Tenggara & 71.20 & 19 \\
\hline 20. & Kalimantan Utara & 71.15 & 20 \\
\hline 21. & Kalimantan Tengah & 70.91 & 21 \\
\hline 22. & Kalimantan Selatan & 70.72 & 22 \\
\hline 23. & Sumatera Selatan & 70.02 & 23 \\
\hline 24. & Lampung & 69.57 & 24 \\
\hline 25. & Sulawesi Tengah & 69.50 & 25 \\
\hline 26. & Maluku & 69.45 & 26 \\
\hline 27. & Maluku Utara & 68.70 & 27 \\
\hline 28. & Gorontalo & 68.49 & 28 \\
\hline 29. & Nusa Tenggara Barat & 68.14 & 29 \\
\hline 30. & Kalimantan Barat & 67.65 & 30 \\
\hline 31. & Sulawesi Barat & 65.73 & 31 \\
\hline 32. & Nusa Tenggara Timur & 65.23 & 32 \\
\hline 33. & Papua Barat & 64.70 & 33 \\
\hline 34. & Papua & 60.84 & 34 \\
\hline & Indonesia (Rata-Rata) & 71.92 & - \\
\hline
\end{tabular}

Sumber: Badan Pusat Statistik(2019)
Indeks Pembangunan Manusia (IPM) merupakan indikator tingkat pembangunan manusia suatu wilayah, yang dihitung melalui perbandingan dari angka harapan hidup, pendidikan dan standar hidup layak. UNDP (United Nation Development Programme) mendefinisikan pembangunan manusia sebagai suatu proses untuk memperluas pilihan-pilihan bagi penduduk. Dalam konsep tersebut penduduk ditempatkan sebagai tujuan akhir (the ultimated end) sedangkan upaya pembangunan dipandang sebagai sarana (principal means) untuk mencapai tujuan itu. Untuk menjamin tercapainya tujuan pembangunan manusia, empat hal pokok yang perlu diperhatikan adalah produktivitas, pemerataan, kesinambungan, pemberdayaan (United Nations Development Programme, 2019).

Berdasar data dari BPS, angka IPM Papua tahun 2010 adalah 54,45, lalu meningkat setiap tahun. Walau demikian, angka IPM Papua hingga tahun 2019 sebesar 60,84 masih jauh di bawah tingkat IPM rata-rata nasional sebesar 71,92. Dari data tersebut dapat disimpulkan bahwa dana pendidikan pada otonomi khusus penggunaanya belum efektif. Dengan kata lain, tambahan dana otonomi khusus setiap tahun tidak berpengaruh signifikan terhadap peningkatan IPM Papua.

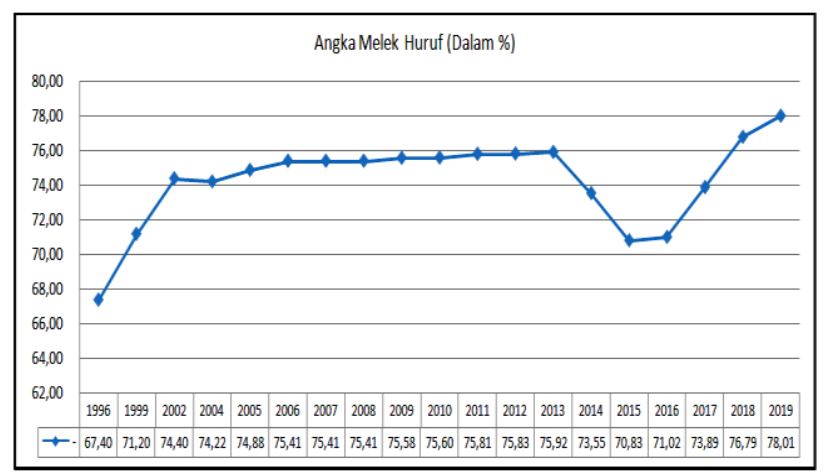

Gambar 1. Angka Melek Huruf Provinsi Papua (BPS, 2019)

Dari grafik di atas dapat dilihat bahwa kondisi angka melek huruf sebelum dan sesudah pemberian dana otonomi khusus tidak signifikan kenaikannya. perbandingan angka melek huruf tahun 1999 dan 2002 mengalami peningkatan sebesar sekitar 3,2\%. Pada tahun 2002 merupakan tahun pertama pengucuran dana otonomi khusus, kenaikan ini dapat disebabkan Pemerintah Provinsi Papua masih melakukan perencanaanperencanaan untuk pengalokasian dana otonomi khusus. Pada tahun 2016 angka melek huruf sebesar 71,02\%, angka ini mengalami penurunan dibandingkan dengan aka melek huruf pada tahun 1999 dan 2002. Namun pada tahun 2019 angka ini naik menjadi 78,01\%. Kenaikan tersebut dirasakan masih belum signifikan jika dibandingkan dengan dana otonomi khusus untuk bidang pendidikan sebesar 30\% dari keluruhan dana otonomi khusus. Hal ini dapat disebabkan oleh belum optimalnya pengelolaan dana otonomi khusus di bidang pendidikan. Ini diperkuat dengan laporan BPK bahwa diduga terdapat penyelewengan dana otonomi khusus di bidang pendidikan pada tahun 2011-2017.

Dana pendidikan yang termasuk di dalam dana otonomi khusus ini kebanyakan hanya dipergunakan untuk membangun gedung sekolah secara fisik saja namun tidak dibarengi dengan peningkatan kualitas pendidikan. Banyak sekolah-sekolah dibangun oleh pemerintah tetapi guru dan penunjang pendidikan lainnya tidak tersedia. Ketersediaan infrastruktur pendidikan menjadi salah satu sebab rendahnya angka Rataan 
Lama Sekolah (RLS) Papua. Angka RLS menjadi acuan dalam kualitas pendidikan dalam suatu provinsi di Indonesia. Semakin maju kualitas pendidikan suatu provinsi, maka semakin tinggi juga angka RLS provinsi tersebut. Perlu dicatat bahwa nilai RLS akan mempengaruhi indikator kemajuan lainnya, seperti Indeks Pembangunan Manusia (IPM) dan angka melek huruf.

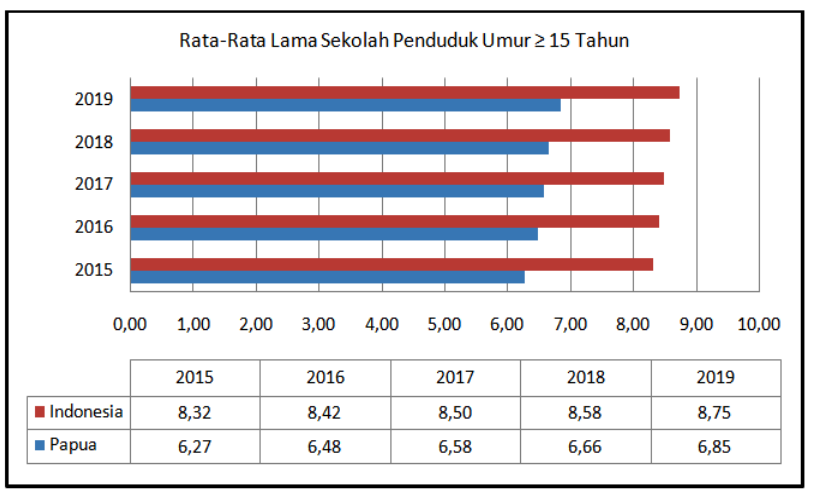

Gambar 2. Rataan Lama Sekolah (RLS) Papua (BPS, 2019)

Dari grafik di atas dapat dikatakan bahwa salah satu permasalahan Provinsi Papua adalah penyediaan fasilitas umum seperti sekolah, fasilitas kesehatan dasar, serta akses jalan penghubung desa-kota. Penyediaan sumber daya guru juga diperlukan, baik fisik dan non-fisik.

\section{Kesehatan}

Problematika sistem kesehatan Papua sangatlah rumit, serumit masalah pelanggaran HAM dan politiknya. Hal itu disebabkan oleh saling terkait antara dimensi pelanggaran HAM, kesehatan dan Politik. Bahkan lebih dari itu, semua sektor saling berkorelasi dan mempengaruhi. Kerumitan itu, selain karena alasan klasik: geografis yang sulit, juga karena kurangnya tenaga SDM kesehatan, fasilitas kesehatan yang tidak memadai, hingga pelayanan kesehatan yang buruk dan metodenya yang kurang tepat.

Masalah mendasar tentang kesehatan Papua terbagi dalam empat hal, yakni: minimnya tenaga SDM kesehatan, minimnya fasilitas kesehatan, rendahnya kualitas dan komitmen pelayanan kesehatan dari petugas medis, serta pendekatan pelayanan yang kurang tepat. Keempat faktor ini diduga sangat erat kaitannya dengan faktor politis awal penguasaan wilayah Papua dengan mengabaikan sisi manusia Papua. Terbukti melalui buruknya sistem pendidikan, kesehatan serta monopoli diskriminasi dalam aspek ekonomi, sosial dan kebudayaan orang Papua. Bahkan sejak Orde Baru, Papua secara sistemik telah "dianaktirikan" dari fokus perhatian pembangunan yang sentralistik dari Jakarta. Kondisi ini telah melahirkan perasaan anti-Indonesia dari hampir mayoritas rakyat Papua hingga selalu berujung pada aspirasi kemerdekaan bagi Papua hingga kini.

UUD NRI 1945 dan Konstitusi Organisasi Kesehatan Dunia (WHO, 2019), serta UU Nomor 36 Tahun 2009 tentang Kesehatan, menetapkan bahwa kesehatan adalah hak asasi manusia yang merupakan hak fundamental setiap warga negara. Dalam UU Nomor 36 Tahun 2009 disebutkan bahwa pembangunan kesehatan bertujuan meningkatkan kesadaran, kemauan dan kemampuan hidup sehat bagi setiap orang agar terwujud derajat kesehatan masyarakat yang setinggitingginya, sebagai investasi bagi pembangunan sumber daya manusia yang produktif secara sosial dan ekonomis.

86 Rindang Mustikawati dan Arief Maulana
Pembangunan kesehatan tersebut diselenggarakan dengan berasaskan peri kemanusiaan, keseimbangan manfaat, perlindungan, penghormatan terhadap hak dan kewajiban, keadilan gender dan non-diskriminatif dan norma-norma agama.

Langkah dan kebijakan pemerintah untuk mewujudkan hal tersebut, salah satunya dengan menerbitkan Instruksi Presiden Nomor 9 Tahun 2017 tentang Percepatan Pembangunan Kesejahteraan di Provinsi Papua dan Provinsi Papua Barat. Inpres tersebut memfokuskan pada sektor kesehatan dan pendidikan, pengembangan ekonomi lokal, infrastruktur dasar, infrastruktur digital, serta konektivitas.

Sesuai aturan WHO, rasio ideal antara dokter dan penduduk adalah 40: 100.000 jiwa, sementara di Papua baru mencapai angka 25:100.000 jiwa. Menurut Data Dinas Kesehatan Papua (2017), di Papua hanya terdapat 316 dokter umum, 85 dokter spesialis, 36 dokter gigi, 1.309 bidan, 4.266 perawat dan 279 tenaga farmasi. Sedangkan pada tahun 2018 meningkat menjadi 774 dokter umum, 251 dokter spesialis, 101 dokter gigi, tenaga kesehatan lain 789, dan farmasi 528 orang. Jumlah ini tentu sangat terbatas, mengingat jumlah populasi penduduk Papua sudah mencapai 3,5 juta jiwa. Papua membutuhkan setidaknya 1.400 dokter untuk mencapai rasio ideal tadi. Dilihat dari segi jumlah tenaga medis secara nasional, Papua termasuk dalam provinsi yang sangat minim akan jumlah tenaga kesehatan.

Menurut hasil FGD dengan Kementerian Kesehatan, masalah tersebut disebabkan oleh beberapa faktor: 1) belum terpenuhinya pengembangan dan pemberdayaan SDM kesehatan; 2) lemahnya perencanaan kebijakan dan program SDM kesehatan; 3) belum adanya dukungan sistem informasi SDM kesehatan yang memadai; 4) belum sinkronnya pemetaan kebutuhan tenaga ahli kesehatan dan distribusinya; 5) pendayagunaan SDM kesehatan dan pemerataan ahli esensial bidang kesehatan masih belum optimal; dan 6) sistem penghargaan dan sanksi bagi SDM kesehatan yang belum diberlakukan secara optimal.

Dalam konteks keterbatasan SDM kesehatan ini, juga disebabkan oleh rendahnya mutu dan kualitas lembaga pendidikan kesehatan di Papua yang berakibat banyaknya SDM kesehatan yang tidak terserap di sektor pelayanan kesehatan. Selain itu, jika diamati barangkali disebabkan pula oleh banyaknya praktisi kesehatan yang berkiprah di dunia politik, wiraswasta, perbankan, hingga LSM-LSM kesehatan maupun nonkesehatan lainnya. Ketersediaan fasilitas kesehatan di Papua masih menjadi masalah serius. Yang dimaksud fasilitas kesehatan ini misalnya tersedianya rumah sakit berstandar nasional, Puskesmas, Polindes hingga Pustu yang merata di seluruh wilayah Papua.

Terdapat beberapa kabupaten yang hingga tahun 2015 silam belum memiliki rumah sakit, misalnya Kabupaten Dogiay, Deiyai, Waropen, Intan Jaya, Puncak, Nduga, Tolikara, Mamberamo Tengah, Yalimo dan Sarmi. Sedangkan pada tahun 2017 total rumah sakit sudah mencapai 36 unit, Puskesmas 394 unit, Posyandu 3.085 unit, Polindes 967 unit. Dari jumlah ini yang masih menjadi persoalan adalah ada tidaknya fasilitas yang memadai dalam meningkatkan mutu dan efektivitas pelayanan kesehatan kepada masyarakat secara optimal. Sebab, banyak Puskesmas yang ditemukan masih kosong, akibat ditinggalkan oleh petugasnya. Begitupun rumah sakit yang sudah ada bangunannya, namun sering kali didapatkan tidak 
adanya fasilitas operasional dasar sebagai kriteria standar pelayanan minimun.

Untuk menghadapi masalah dan tantangan kesehatan di Papua diperlukan percepatan pembangunan di bidang tersebut. Di lain pihak, butuh sebuah terobosan besar yang dapat memberikan hasil terukur dalam waktu relatif singkat serta langsung dirasakan oleh masyarakat. Adanya pelayanan kesehatan yang prima (fasilitas dan SDM kesehatan yang memadai, komitmen pelayanan bagi kemanusiaan yang utuh, dan pendekatan pelayanan yang tepat sehingga hidup masyarakat sehat dan sejahtera) bagi rakyat Papua akan menjadi suatu indikasi keberhasilan negara dalam memenuhi hak-hak warganya dalam bidang kesehatan.

\section{Kemiskinan}

Berdasarkan data BPS, tingkat kemiskinan di Provinsi Papua pada Maret 2018 sebesar 27,74\% atau lebih dari seperempat dari populasi. Namun, pada Maret 2019 angka kemiskinan di provinsi paling timur Indonesia tersebut turun menjadi 27,53\%. Meskipun, angka tersebut sedikit turun, namun persentase penduduk miskin di 17 kabupaten/kota Provinsi Papua pada 2018 berada di atas angka kemiskinan provinsi yang sebesar 27,43\%. Bahkan, sebanyak tiga kabupaten, yakni Deiya, Intan Jaya, dan Lanny Jaya tingkat kemiskinannya di atas $40 \%$ dari populasi. Jumlah penduduk yang masuk kategori miskin sebanyak 918 ribu jiwa pada Maret 2018. Angka ini meningkat menjadi 926 ribu jiwa pada Maret 2019, namun secara persentase masih menunjukkan sedikit penurunan. Sebanyak 41 ribu jiwa penduduk miskin Papua tinggal di kota, sedangkan 885 ribu penduduk miskin tinggal di perdesaan pada 2019.

Minimnya infrastruktur yang terkait pendidikan, kesehatan dan kesejahteraan masyarakat diduga menjadi penyebab kemiskinan di wilayah Papua. Semakin tinggi tingkat pendidikan dan kesejahteraan masyarakat suatu kabupaten/kota diharapkan semakin sejahtera masyarakatnya. Pada akhirnya inilah yang membuat orang/keluarga bisa keluar dari garis kemiskinan. Selain itu, aksesibilitas di wilayah Papua masih cenderung sulit akibat dari kondisi topografi wilayahnya yang dipisahkan oleh pegunungan, lembah, ataupun tersebar di pulau-pulau kecil. Kondisi keterisolasian ini pun menyebabkan terhambatnya mobilitas penduduk, distribusi barang dan jasa, hingga penyelenggaraan layanan dasar kepada masyarakat. Secara umum, kemisikinan di Papua dapat digambarkan sebagai berikut:

a. Badan Pusat Statisik (BPS) Provinsi Papua merilis presentase penduduk miskin pada Maret 2019 naik 0,10 persen. Presentase ini meningkat sepanjang 6 bulan terakhir, baik di daerah perkotaan dan pedesaan. Data BPS Papua menyebutkan penduduk miskin perkotaan naik 0,25 persen dan pedesaan naik 0,19 persen.

b. Penduduk miskin di Papua terkonsentrasi di daerah pedesaan, di mana pada Maret 2019 terdapat 885, 35 ribu jiwa atau 36, 84 persen, sedangkan di perkotaan berkisar 41,01 ribu jiwa atau 4,26 persen. Artinya, secara keseluruhan menurut daerah, penduduk miskin yang tinggal di kota maupun tinggal di desa di wilayah Papua tercatat sebanyak 926, 36 ribu jiwa.

c. $74,24 \%$ penduduk asli tinggal di daerah-daerah terpencil dengan akses pada infrastruktur dan fasilitas perhubungan yang sangat terbatas, atau bahkan tidak ada sama sekali; d. Dipandang dari segi produksi pertanian, ekonomi, pendidikan, kesehatan dan penguasaan teknologi, kurang lebih $80 \%$ dari keluarga-keluarga hidup dalam kemiskinan dan konsisi terbelakang;

e. Harga-harga barang konsumsi di kota-kota kabupaten ratarata 45\% lebih mahal dari pada di tempat lain di Indonesia.

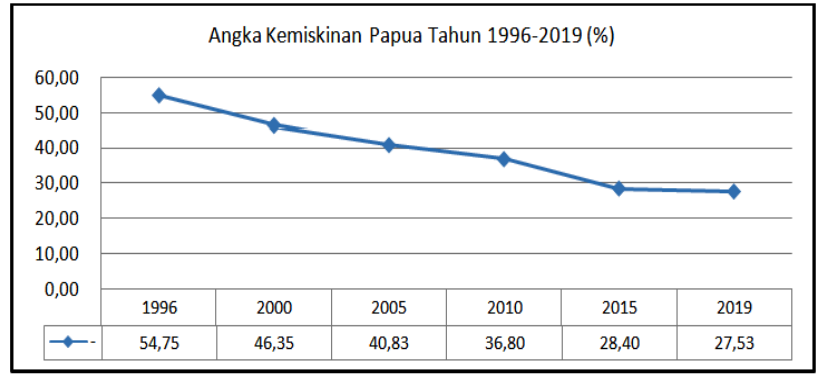

Gambar 3. Angka Kemiskinan Provinsi Papua (BPS, 2019)

Grafik di atas menggambarkan persentase kemiskinan Provinsi Papua dari tahun 1996-2019. Pada tahun 1996 presentase kemiskinan di Provinsi Papua mencapai lebih dari 50\%. Hal ini dapat diartikan bahwa lebih dari 50\% masyarakat Papua berada di garis kemiskinan. Dari data tersebut dapat dilihat bahwa tren persentase kemiskinan dari tahun ketahun semakin menurun. Namun demikian, program pengentasan kemiskinan di Provinsi Papua masih banyak berupa bantuan langsung bukan bantuan modal. Sehingga dengan kondisi masyarakat Papua yang konsumtif bantuan secara langsung tersebut hanya habis dipakai untuk belanja sehari-hari saja.

\section{Problem Evaluasi Dana Otonomi Khusus Papua}

Ketidakefektifan implementasi Otonomi khusus Papua disebabkan oleh tidak adanya pengawasan dan supervisi dari pemerintah pusat kepada pemerintah daerah pada masa transisi proses desentralisasi ini. UU Otonomi khusus Papua dan pelaksanaannya tidak dievaluasi secara rutin dan komprehensif. Seharusnya, evaluasi dilakukan secara berkala setiap tiga tahun sesuai dengan ketentuan di dalam UU Otonomi Khusus Papua. Meskipun dilakukan evaluasi, hal itu bersifat parsial tidak bersifat menyeluruh serta tidak dipublikasikan secara luas seperti yang dilakukan oleh Universitas Cenderawasih. Idealnya, pengawasan harus dilakukan bukan dalam rangka mencari-cari kesalahan, tetapi karena tiga hal yaitu (1) jaminan (assurance), (2) bimbingan (consultant), dan (3) katalisator (catalyst). Pertama, assurance berfungsi untuk menjamin bahwa produk atau jasa yang dihasilkan oleh instansi pemerintah memenuhi kualitas yang diharapkan masyarakat. Kedua, consultant diperlukan untuk memberi bimbingan atau pendampingan kepada instansi pemerintahan agar kegiatan dapat dilaksanakan sesuai dengan ketentuan dan mencapai sasaran yang diharapkan. Ketiga, catalyst dibutuhkan agar pelaksana kegiatan di instansi pemerintahan dapat menggali sendiri kecukupan pengendalian, mengidentifikasi dan mengevaluasi resiko, serta membuat rencana tindakan untuk mendorong proses perbaikan.

Pada dasarnya, evaluasi dana otonomi khusus telah dinyatakan dalam Perdasus Nomor 13 Tahun 2016 bahwa pengawasan pengelolaan dana otonomi khusus meliputi:

a. Pengawasan intern, dilaksanakan melalui proses audit, reviu, evaluasi, pemantauan dan kegiatan pengawasan lain dalam rangka memberikan keyakinan yang memadai bahwa keuangan otonomi khusus dikelola secara efisien, efektif, 
tertib, transparan, dan akuntabel, yang dilaksanakan oleh inspektorat provinsi/kabupaten/ kota.

b. Pengawasan DPRD, dilaksanakan melalui pengawasan Perdasus, Perda Kabupaten/ Kota, Peraturan Gubernur, dan Peraturan Bupati/Walikota dan tindak lanjut hasil pemeriksaan yang terkait dengan dana otonomi khusus.

c. Pengawasan MRP, dilaksanakan melalui permintaan keterangan dari pemerintah provinsi/kabupaten/kota tentang pelaksanaan Perdasus/Perda, peraturan gubernur/ bupati/walikota yang mengatur pengelolaan dana Otonomi Khusus, dan pemantauan/penilaian terhadap program/ kegiatan pembangunan yang dibiayai dari sumber dana Otonomi Khusus.

d. Pengawasan masyarakat, dilaksanakan oleh individu atau kelompok warga yang ditujukan untuk menilai dan memberi masukan untuk perbaikan pelaksanaan program dan kegiatan yang dibiayai dari dana Otonomi Khusus.

Akibat pengawasan berlapis yang masih lemah, praktik korupsi, kolusi atau nepotisme masih tumbuh subur di Papua. Aparat pemerintah nasional yang tidak tegas ditambah dengan lemahnya pengawasan internal provinsi menyebabkan korupsi, kolusi atau nepotisme menjadi tindakan yang jamak. Kondisi ini menggambarkan bahwa seolah-olah, baik pemerintah pusat maupun gubemur sebagai kepanjangan tangan dari pemerintah nasional melakukan pembiaran karena kekhawatiran meningkatnya ancaman disintegrasi. Dampaknya, dana otonomi khusus Papua tidak sepenuhnya dirasakan sampai ke masyarakat akar rumput, tapi hanya berhenti di tingkat para elite daerah. Justru situasi semacam ini yang dalam kenyataannya semakin memperbesar kelompok-kelompok yang antipati terhadap pendekatan kesejahteraan yang dilakukan negara melalui dana otonomi khusus.

\section{KESIMPULAN}

Dari pembahasan di atas dapat disimpulkan bahwa dana otonomi khusus Papua mulai berdampak baik dari sektor pendidikan, kesehatan, ekonomi atau pengentasan kemiskinan. Namun dampak tersebut belum signifikan mengingat pertumbuhannnya yang sangat lambat bila dibandingkan dengan besarnya jumlah dana otsus yang dialokasi setiap tahun. Jika ditinjau dari konsep dan tujuan otonomi daerah, ini disebabkan oleh sistem kelembagaan pemerintahan yang belum bekerja secara efektif dan efisien maupun dalam kualitas dan kuantitas sumber daya manusia yang ada. Selain itu, dana otonomi khusus yang dialokasikan untuk kabupaten/kota, program-programnya masih terpusat di Provinsi sehingga kabupaten/kota hanya menjadi pelaksana saja. Selain itu, pengawasan yang hanya dilakukan di lingkup internal menyebabkan banyaknya penyimpangan untuk dana otonomi khusus tersebut.

Secara umum, menilai berhasil atau tidaknya Otonomi Khusus Papua memang debatable. Sebagian kalangan menilai otonomi khusus berhasil karena membawa banyak perbaikan di Papua, namun sebagian lainnya menilai otonomi khusus gagal karena perubahan yang tidak signifikan berbanding terbalik dengan besarnya jumlah dana otsus yang dialokasi. Di kalangan pemerintahan daerah misalnya, Otonomi Khusus Papua (khususnya dana otononi khusus) sangat penting dan karenanya harus dilanjutkan. Tidak demikian halnya dirasakan sebagian besar masyarakat Papua, yang menurut mereka tidak banyak manfaat untuk kesejahteraan masyarakat Papua.

Banyak argumen dan dasar alasan yang bisa digunakan untuk memberi jawaban, apakah gagal atau diterima sebagai sesuatu proses yang wajar terkait kompleksitas dan besarnya persoalan yang dihadapi pemerintah dalam melaksanakan Otonomi Khusus Papua. Logika sederhana akan mengatakan bahwa pelaksanaan otonomi khusus gagal jika disandingkan dengan fakta yang ada bahwa selama 20 tahun masih banyak ditemui fakta yang ironis dan memprihatinkan di tanah Papua. Sesungguhnya banyak persoalan yang lebih mendasar yang membuat sebuah kebijakan yang sejak awal dimaksudkan untuk memberdayakan masyarakat Papua itu belum mencapai hasil yang diharapkan.

\section{REKOMENDASI}

Dari kesimpulan tersebut, hal-hal yang perlu direkomendasikan guna menyelesaikan permasalahanpermasalahan terkait dana otonomi khusus Papua adalah sebagai berikut:

1. Pembangunan bidang pendidikan, Kesehatan dan pengentasan kemiskinan di Papua harus dikuatkan dengan pemberdayaan SDM Papua melalui peningkatan fasilitas, sarana dan prasarana pendidikan dan kesehatan, serta peningkatan bantuan modal untuk rakyat miskin.

2. Pemerintah perlu mengkaji ulang perbaikan mekanisme penyaluran, pemanfaatan dan pengawasan dana otonomi khusus agar lebih efektif, efisien, tepat sasaran dan tepat guna dengan memperhatikan tata kelola yang lebih baik;

3. Pemerintah perlu mendorong Pemerintah Provinsi Papua dan Pemerintah Kabupaten/ Kota di seluruh Papua agar lebih memprioritaskan penggunaan dana otonomi khusus dalam upaya peningkatan kesejahteraan dan pelayanan publik dengan memfokuskan pada sektor pendidikan dan kesehatan, dengan memperhatikan karakteristik demografi, sosial ekonomi, adat, budaya dan politik keamanan.

Pemerintah perlu meningkatkan koordinasi dan komunikasi secara intensif dengan jajaran pemerintahan di Papua dalam melakukan pengawasan atas pengelolaan dana otonomi khusus yang lebih efektif dan optimal.

\section{REFERENSI}

Badan Pusat Statistik. (2019). Profil Kemiskinan di Indonesia. https://www.bps.go.id/pressrelease/2019/

07/15/1629/persentase-penduduk-miskin-maret-2019-

sebesar-9-41-persen.html. Diakses 21 Juli 2019.

Cresswell, J. W. (2009). Research Design: Qualitative, Quantitative, and Mixed Methods Approaches. California: SAGE Publication.

Djojosoekarto, A. (2008). Kebijakan Otonomi Khusus di Indonesia: Pembelajaran dari Kasus Aceh, Papua, Jakarta dan Yogyakarta. Jakarta: Kemitraan.

Haryanto, J. T. (2017). Desentralisasi Fiskal Seutuhnya. https://www.kemenkeu.go.id/publikasi/artikel-danopini/desentralisasi-fiskal-seutuhnya/\%0A

Mardiasmo. (2009). Otonomi dan Manajemen Keuangan Daerah. Yogyakarta: Andi Press.

Rochendi S, \& Saleh, K. A. S. (2017). Hubungan Pemerintah Pusat dan Daerah Dalam Otonomi Khusus di Provinsi Papua Barat. Jurnal Kajian Politik Dan Masalah Pembangunan, 13(1). http://journal.unas.ac.id/politik/article/view/231 
Sasana, H. (2015). Dampak Implementasi Desentralisasi Fiskal Terhadap Pertumbuhan Ekonomi dan Stabilitas Harga di Provinsi-Provinsi di Indonesia. Jurnal Media Ekonomi Dan Manajemen Untag Semarang, 30(2), 161. http://jurnal.untagsmg.ac.id/index.php/fe/article/view/230

Solossa, J. P. (2006). Otonomi Khusus Papua: Mengangkat Martabat Rakyat Papua Dalam NKRI. Jakarta: Pustaka Sinar Harapan.

Sugandi, Y. (2008). Analisis Konflik dan Rekomendasi Kebijakan Mengenai Papua. Jakarta: Friedrich Ebert Stiftung.

Suharyo. (2016). Otonomi Khusus di Papua dan Aceh sebagai Perwujudan Implementasi Peranan Hukum Dalam Kesejahteraan Masyarakat. Jurnal RechtsVinding, 5(3), 324. https://rechtsvinding.bphn.go.id/ejournal/index.php/jrv/arti cle/view/148

Tabuni, D., Rumapea, P., \& Aeros, W. A. (2016). Implementasi Kebijakan Otonomi Khusus (Studi Kasus tentang Pelayanan Publik Bidang Pendidikan di Kabupaten Lanny Jaya). Jurnal Administrasi Publik Unsrat, 1(43), 2. https://ejournal.unsrat.ac.id/index.php/JAP/article/view/170 60

Tillin, L. (2006). Tillin, L. 2006. United in Diversity? Asymmetry in Indian Federalism. Publius: The Journal of Federalism, 37(1), 46. https://doi.org/10.1093/publius/pj1017

United Nations Development Programme. (2019). Human Development Index (HDI). 2019.

http://hdr.undp.org/en/content/human-development-index-hdi. Dikases 22 Agustus 2019.

WHO. (2019). Constitution of World Health Organization. 2019. https:/www.who.int/about/who-we-are/constitution. Dikases 22 Agustus 2019.

Widjojo, M. S., \& Budiatri, A. P. (2016). UU Otonomi Khusus Bagi Papua: Masalah Legitimasi dan Kemauan Politik. Jurnal $\begin{array}{lll}\text { Penelitian Politik } & \text { LIPI, }\end{array}$ http://ejournal.politik.lipi.go.id/index.php/jpp/article/view/ 449

Undang-Undang Republik Indonesia Nomor 21 Tahun 2001 tentang Otonomi Khusus Bagi Provinsi Papua

Undang-Undang Republik Indonesia Nomor 35 Tahun 2008 Penetapan Peraturan Pemerintah Pengganti UndangUndang Nomor 1 Tahun 2008 tentang Perubahan Atas Undang-Undang Nomor 21 Tahun 2001 tentang Otonomi Khusus Bagi Provinsi Papua Menjadi Undang-Undang

Undang-Undang Republik Indonesia Nomor 36 Tahun 2009 tentang Kesehatan

Undang-Undang Republik Indonesia Nomor 23 Tahun 2014 Pemerintahan Daerah

Instruksi Presiden Nomor 9 Tahun 2017 tentang Percepatan Pembangunan Kesejahteraan di Provinsi Papua dan Provinsi Papua Barat

Peraturan Daerah Khusus Provinsi Papua Nomor 25 Tahun 2013 tentang Pembagian Penerimaan dan Pengelolaan Keuangan Dana Otonomi Khusus

Peraturan Daerah Khusus Provinsi Papua Nomor 13 Tahun 2016 tentang Perubahan atas Perdasus Provinsi Papua Nomor 25 Tahun 2013 tentang Pembagian Penerimaan dan Pengelolaan Keuangan Dana Otonomi Khusus 